\title{
Comparison of the efficacy of ephedrine and lidocaine for reducing pain on propofol injection in Indonesian adult surgical patients
}

\author{
Mujahidin ${ }^{*}$, Bambang Suryono², Yusmein Uyun ${ }^{2}$ \\ ${ }_{1}^{1}$ SMF Anesthesiology, Harapan Kita National Cardiovascular Center, Jakarta \\ 2 Departement of Anesthesiology, Faculty of Medicine, Universitas Gadjah Mada, \\ Yogyakarta
}

\begin{abstract}
Propofol has been frequently used as an induction and maintenance of general anesthesia. However, it often causes pain at the site of injection. Various premedications have been used to alleviate the propofol-induced pain, but the results does not satisfy. This study was conducted to compare the efficacy of ephedrine and lidocaine for reducing pain on injection of propofol in Indonesian adult surgical patients. This was a double-blind randomized controlled trial study conducted in Dr. Sardjito General Hospital, Yogyakarta and its affiliation hospitals. One hundred and twenty eight patients who underwent elective surgery with general anesthesia and met inclusion and exclusion criteria involved in this study. Patients were allocated into two groups with 64 patients of each group. The first group was patients who given lidocaine $2 \% 40 \mathrm{mg}$ IV (lidocaine group) and the second group was patients who given ephedrine $30 \mathrm{ig} / \mathrm{kg}$ BW IV (ephedrine group). Sixty seconds after lidocaine or ephedrine infusion, patients were then intravenously induced with propofol $2 \mathrm{mg} / \mathrm{kg}$ BW. Clinical pain intensity of patients in both groups was then scored and compared statistically using Chi-Square test. The results showed that no significantly different in pain intensity in group receiving lidocaine infusion in comparison with ephedrine infusion was observed $(p=0.201)$. Moreover, no significantly different in the incidence of pain in both groups was observed $(p=0.068)$. However, clinically ephedrine has the ability to eliminate the pain on propofol injection more better than lidocaine as indicated by lower pain incidence in group receiving ephedrine $(7.8 \%)$ than in group receiving lidocaine $(18.7 \%)$. Patients who have no pain were also higher in group receiving ephedrine $(92,2 \%)$ than in group receiving lidocaine (81.3\%). In conclusion, the efficacy of ephedrine $30 \mu \mathrm{g} / \mathrm{kg} \mathrm{BW}$ IV and lidocaine $2 \% 40 \mathrm{mg}$ IV was comparable for reducing pain on injection of propofol in Indonesian adult surgical patients.
\end{abstract}

\section{ABSTRAK}

Propofol sering digunakan untuk menginduksi dan mempertahankan anestesi umum. Namun demikian propofol sering menyebabkan nyeri pada tempat penyuntikan. Berbagai obat premedikasi telah digunakan untuk meredakan nyeri akibat induksi propofol, namum hasilnya masih belum memuaskan. Penelitian ini dilakukan untuk membandingkan efektivitas efedrin dengan lidokain untuk menurunkan nyeri pada penyuntikan propofol pada pasien bedah dewasa Indonesia. Penelitian ini merupakan penelitian klinik menggunakan rancangan uji terkontrol plasebo secara acak tersamar ganda yang dilakukan di RSUP Dr. Sardjito, Yogyakarta dan rumah sakit afiliasi. Seratus dua puluh delapan pasien yang menjalani bedah elektif dengan anestesi umum dan memenuhi kriteria inklusi dan eksklusi terlibat dalam penelitian ini. Pasien dibagi dalam dua kelompok masing-masing kelompok 64 pasien. Kelompok pertama (kelompok lidokain) adalah

\footnotetext{
* corresponding author: muja311@yahoo.com
} 


\begin{abstract}
pasien yang diberik $40 \mathrm{mg} 2 \%$ lidokain secara IV dan kelompok kedua (kelompok efedrin) adalah pasien yang diberi $30 \mu \mathrm{g} / \mathrm{kg}$ BB efedrin secara IV. Enam puluh menit setelah infus IV lidokain atau efedrin, pasien kemudian diinduksi dengan $2 \mathrm{mg} / \mathrm{kg}$ BB propofol secara IV. Intensitas nyeri pasien kedua kelompok diukur dan dibandingkan secara statistik dengan uji Chi-square. Hasil penelitian menunjukkan tidak ada perbedaan bermakna terhadap intensitas nyeri setelah pemberian infus IV lidokain dibandingkan dengan efedrin $(p=0,201)$. Lebih lanjut terbukti kejadian nyeri pada kedua kelompok juga tidak berbeda nyata $(p=0,068)$. Namun demikian, pemberian efedrin secara klinik mempunyai kemampuan menghilangkan nyeri lebih baik dibandingkan lidokain sebagaimana ditunjukkan kejadian nyeri yang lebih rendah pada kelompok yang diberi efedrin $(7,8 \%)$ dibandingkan kelompok yang diberi lidokain $(18,7 \%)$. Pasien yang tidak merasakan nyeri juga lebih tinggi pada kelompoj yang menerima efedrin $(92,2 \%)$ dibandingkan kelompok yang menerima lidokain $(81,3 \%)$. Dapat disimpulkan, efektivitas efedrin dosis $30 \mu \mathrm{g} / \mathrm{kg}$ BB IV dan $2 \%$ lidokain dosis $40 \mathrm{mg}$ IV sebanding untuk menurunkan nyeri pada penyuntikan propofol pada pasien bedah dewasa Indonesia.
\end{abstract}

Key words: pain - injection - propofol - lidocaine - ephedrine.

\section{INTRODUCTION}

Propofol is a drug of choice for anesthesia induction. It has been frequently used as an induction and maintenance of general anesthesia due to its advantages such as rapid onset, short duration, smooth induction without excitation, minimal drug accumulation, quality conscious recovered quickly, no headaches, minimal psychomotor sequelae, and having an antipruritus and antivomiting effects. ${ }^{1-3}$ Propofol is the most popular induction agent for laryngeal mas airway (LMA) insertion because it give a total intravenous anesthesia (TIVA) and can be used to maintain anesthesia, sedation and to prevent vomiting. Therefore, propofol is often used in some operations such as a short operation, a day surgery cases, surgery cases with high risk of post operative nausea and vomiting (PONV). ${ }^{4,5}$

Although propofol has become a drug of choice for anesthesia induction, however, the incidence of side effects following propofol induction has been reported. Propofol often causes pain at the site of injection. The quality of pain was described as extremely sharp, aching or burning. This propofol side effect has been noted as one of the most important problems in current practice of clinical anesthesia by American anesthesiologist. ${ }^{6-8}$ Moreover, propofol induction was also reported to have cardiovascular side effects, especially hypotension. ${ }^{9}$

Some techniques have been implemented in alleviating pain on propofol injection such as i) injection conducted on a large vein like fossa cubitalis; ii) diluting of propofol preparation; iii) changing the speed of injection and iv) decreasing of propofol preparation temperature during administration. ${ }^{7,10}$ Moreover, the alleviating pain on propofol injection can be performed by a premedication administrat-ion. Some premedications have been used to alleviate the pain of propofol injection such as metoclopramide, lignocaine, ${ }^{11,12}$ pethidine, ${ }^{12}$ ketamine, ${ }^{13}$ fentanyl, ${ }^{14}$ alfentanil,${ }^{15}$ flurbiprofen, ${ }^{16}$ and lidocaine. ${ }^{7,13,14}$

Although many studies have been performed to evaluate premedications for attenuating propofol related injection pain, however, findings from the studies are inconsistent. Therefore, studies to evaluate the efficacy of other premedications for preventing pain on injection of propofol are needed. This study was performed to compare the efficacy of lidocaine $2 \% 40 \mathrm{mg}$ intravenously (IV) and ephedrine $30 \mu \mathrm{g} / \mathrm{kg} \mathrm{BW}$ (body weight) IV for 
reducing pain on injection of propofol in Indonesian adult surgical patients.

\section{MATERIALS AND METHODS}

\section{Study design}

This was a double-blind randomized controlled trial study conducted in Dr. Sardjito General Hospital, Yogyakarta and its affiliation hospital i.e. Banyumas District Hospital, Banyumas District, Central Java, Panembahan Senopati District Hospital, Bantul District, Yogyakarta Special Region, Orthopedi Special Hospital, Solo, Central Java and Saras Husada District Hospital, Purworejo, Central Java. Patients who underwent elective surgery with general anesthesia were randomized and allocated into two groups using a computer program. The first group was patients who given lidocaine 2\% $40 \mathrm{mg}$ IV (lidocaine group) and the second group was patients who given

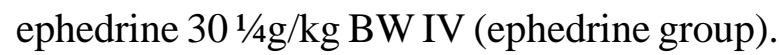
The protocol of study has been approved by the Medical and Health Research Ethic Committee, Faculty of Medicine, Universitas Gadjah Mada, Yogyakarta.

\section{Subjects}

One hundred and twenty eight patients, 64 patients of each group, who met inclusion and exclusion criteria involved in this study. The inclusion criteria were men or women between the age 18-60 years old, with the Body Mass Index (BMI) between 17.5 to $24.5 \mathrm{~kg} / \mathrm{m}^{2}$ and ASA physical status I or II, underwent elective surgery with general anasthesia, cooperative and willing to be involved in this study as expressed by signing a inform consent. The exclusion criteria were patients with severe hepatic impairment, phychological and neurological disorders, hipertension, using analgesic and sedative drugs 24 hours before surgery, thrombophleblitis or dorsal vein disorders of the hand, multiple trauma and severe bleeding, and cardiac conduction abnormalities.

\section{Protocol of study}

An explanation concerning the background, objectives, benefits of the study was informed before study. Subject who willing to participate in this study was given an informed consent to be signed. Subject then underwent anamnesis and physical examination. The subject who met the inclusion and exclusion criteria was recruted and randomly allocated to one of two groups. The ringer's lactate solution was administered intravenously with a catheter IV no. 18 in a large peripheral vein of left or right arm. In the operating room, hemodynamic status of subjects i.e. blood pressure (BP), heart rate (HR), mean arterial blood pressure (MAP), oxygene saturation $\left(\mathrm{SpO}_{2}\right)$, electrocardiogram (ECG) were measured and recorded as base line data. The subjects in lidocaine group were given given $2 \%$ lidocaine $40 \mathrm{mg}$ intravenously, while the subjects in ephedrine group were given ephedrine $301 / 4 \mathrm{~g} / \mathrm{kg}$ BW intravenously. All subjects in both group were not given premedications. Sixty seconds after infusion, subjects were then intravenously induced with propofol $2 \mathrm{mg} / \mathrm{kg}$ BW. Clinical pain intensity of subjects in both group was scored as described by Fauzia et al. ${ }^{13}$ as follows 0 as no pain; 1 as mild pain (no change in facial expression); 2 as pain (no change patient behavior to move the fingers but not pull the hand and 3 as severe pain (no pull of the hands of patients). One minute after induction as indicated by the negative reflect of eyelash, the hemodynamic status of subjects (BP, HR, MAP, $\mathrm{SpO}_{2}$ and ECG) were monitored again and recorded. Anesthesia was then maintained as available standard operating procedure. 


\section{Statistical analysis}

Continous variable data (age, body weight, body height, MAP, diastolic and sistolic BP, $\mathrm{HR}, \mathrm{SpO}_{2}$ ) of both groups were presented as mean \pm standard deviation (SD) and analyzed with independent t-test. Categorical variable data (gender, physical status, pain sensitivity, and advers drug reaction) of both groups were presented as proportion or percentage and analyzed with Chi-Square test. All statistical analysis were performed using SPSS software version 1.6 with $p$ value $<0.05$ as considered significant.

\section{RESULTS}

Sixty four patients in lidocaine group and 64 patients in ephedrine group were involved in this study. The characteristics of patients in both groups are presented in TABLE 1 . No significant difference $(p>0.05)$ in age, body height, body weight, BMI, sex and ASA physical status of patients between the two groups were observed indicating that the characteristics of patients in both groups were similar.

TABLE 1. Characteristics of subjects of lidocaine and ephedrine groups

\begin{tabular}{lccc}
\hline Variables & Lidocaine group & Ephedrine group & $\mathrm{p}$ \\
\hline Age (year) & $37.39 \pm 12.67$ & $34.67 \pm 13.18$ & 0.236 \\
Height $(\mathrm{cm})$ & $160.22 \pm 6.82$ & $160.19 \pm 7.87$ & 0.981 \\
Weight $(\mathrm{kg})$ & $52.17 \pm 6.73$ & $53.27 \pm 8.72$ & 0.429 \\
BMI $\left(\mathrm{kg} / \mathrm{m}^{2}\right)$ & $20.31 \pm 2.18$ & $20.78 \pm 3.32$ & 0.339 \\
Sex $(\mathrm{n} / \%)$ & & & \\
$\bullet \quad$ Male & $31(49 \% \%)$ & $32(51 \%)$ & 0.860 \\
- Female & $33(51 \%)$ & $32(49 \%)$ & \\
ASA physical status $(\mathrm{n} / \%)$ & & & 0.857 \\
$\bullet \quad$ I & $38(49 \%)$ & $39(51 \%$ & \\
• II & $26(51 \%)$ & $25(49 \%)$ & \\
\hline
\end{tabular}

FIGURE 1 shows pain intensity in patients receiving lidocaine $2 \% 40 \mathrm{mg}$ IV and ephedrine $30 \mu \mathrm{g} / \mathrm{kg}$ BW IV. No significantly different in pain intensity in both groups was observed $(p=0.201)$. It was indicated that the efficacy of ephedrine in alleviating the incidence and severity of propofol injection was not different from lidocaine. 


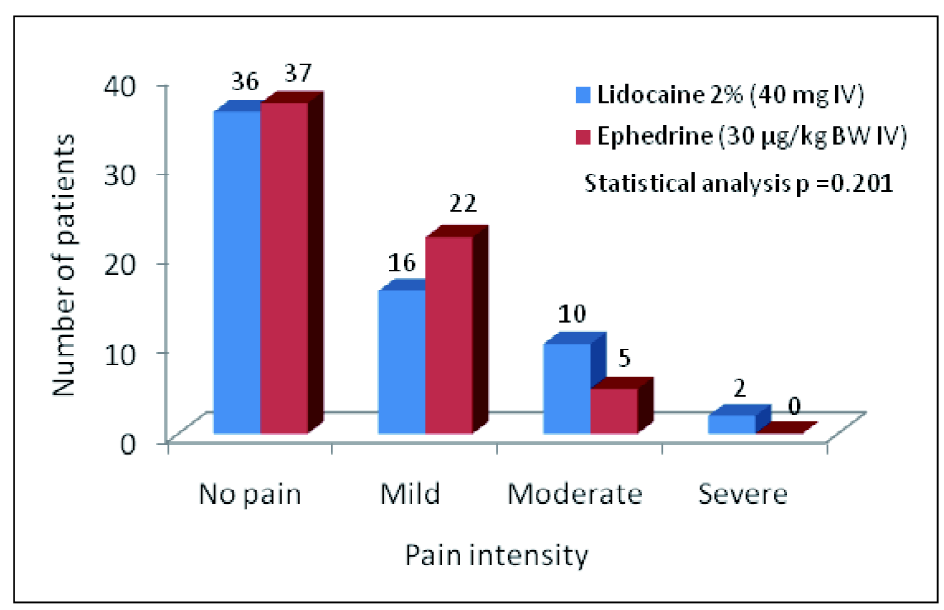

FIGURE 1. Pain response in groups receiving $40 \mathrm{mg}$ lidocaine $2 \% \mathrm{IV}$ and $30 \mu \mathrm{g} / \mathrm{kg} \mathrm{BW}$ ephedrine IV

TABLE 2 shows the incidence of propofol injection pain in groups receiving lidocaine $2 \%$ $40 \mathrm{mg}$ IV and ephedrine $30 \mu \mathrm{g} / \mathrm{kg}$ BW IV. No significantly different in the incidence of pain in both groups was observed $(\mathrm{p}=0.068)$. However, clinically ephedrine has the ability to eliminate the pain on propofol injection more better than lidocaine as indicated by lower pain incidence in group receiving ephedrine $(7.8 \%)$ than in group receiving lidocaine $(18.7 \%)$. Moreover, patients who have no pain were higher in group receiving ephedrine $(92,2 \%)$ than in group receiving lidocaine $(81.3 \%)$.

TABLE 2. Incidence of pain on propofol injection in groups receiving lidocaine $2 \% 40 \mathrm{mg}$ IV and ephedrine $30 \mu \mathrm{g} / \mathrm{kg} \mathrm{BW}$ IV

\begin{tabular}{lccc}
\hline Pain response & Lidocaine group & Ephedrine group & $\mathrm{p}$ \\
\hline Pain & $12(18.7 \%)$ & $5(7.8 \%)$ & \\
No pain & $52(81.3 \%)$ & $59(92.2 \%)$ & 0.068 \\
Total & $64(100 \%)$ & $64(100 \%)$ & $128(100 \%)$ \\
\hline
\end{tabular}

\section{DISCUSSION}

Propofol has been commonly used for induction and maintenance of general anesthesia. However, pain caused by propofol injection can be extremely distressing to the patients. ${ }^{7,8}$ The study reported that the incidence pain on propofol injection is $28 \%$ to $90 \%$ in adults and $28 \%$ to $85 \%$ in children. ${ }^{7}$ Various pharmacological and non-pharmacological interventions have been conducted to eliminate the propofol-induced pain. ${ }^{7,10,16}$
Lidocaine pretreatment has been reported to be the most populer premedication for attenuating propofol related injection pain. ${ }^{14-17}$ Lidocaine given mixed with propofol was effective in alleviating pain on propofol injection. The increasing lidocaine dosage significantly reduced pain during propofol injection. ${ }^{18}$ Lidocaine was also reported reduce the incidence of pain on propofol injection in comparison with normal saline control. ${ }^{19}$ 
The mechanism of action of lidocaine in reducing pain on propofol injection has been postulated. Lidocaine plays role in $\mathrm{pH}$ reduction, propofol concentration reduction in aqueous phase, and as local anesthetic on blood vessel. ${ }^{20}$ Moreover, as a local anesthetic, lidocaine is well known as a membrane stabilizing drug. Lidocaine reversibly decrease the rate of depolarization and repolarization of excitable membranes leading to an inhibition of the kininogens release. ${ }^{3}$

This study was conducted to evaluate whether the the efficacy of ephedrine more better than lidocaine for reducing pain on injection of propofol. Lidocaine was used as positive control due to its popularity for reducing pain on propofol injection. The results of this study showed that the efficacy of ephedrine in alleviating the incidence and severity of propofol injection was not different from lidocaine. Furthermore, the incidence of pain after ephedrine pretreatment was not significantly different compare to lidocaine pretreatment. However, clinically ephedrine has the ability to eliminate the pain on propofol injection more better than lidocaine. Therefore, ephedrine could be considered as an alternative premedication for reducing pain on propofol injection.

The use of ephedrine for reducing pain has been investigated by some authors. Cheong et $a l .{ }^{21}$ reported that pretreatment with a small dose of epehidrine (30 and $70 \mu \mathrm{g} / \mathrm{kg} \mathrm{BW}$ ) reduced the incidence and intensity pain on propofol induction without significant adverse hemodynamic effects during induction. It was also reported that adding ephedrine $30 \mathrm{mg}$ to $20 \mathrm{~mL}$ of $1 \%$ propofol is as effective as lidocaine adding in preventing pain on propofol injection and it resulted in more stable in hemodynamic profile. ${ }^{22}$

The mechanism of ephedrine in reducing pain on injection of propofol may be associated with its pharmacodynamics properties.
Ephedrine pretreatment one minute before propofol injection will stimulate the norepinephrine release leading to inhibition of the substance P release in cornu dorsal medulla spinalis and free nerve endings such as vascular. Substance $\mathrm{P}$ is an important element in pain perception. Substance $P$ is involved in nociception, transmitting information about tissue damage from peripheral receptors to the central nervous system to be converted to the sensation of pain. The inhibition of the substance $\mathrm{P}$ release by norepinephrine after ephedrine pretreatment causes an impairment of pain perception. ${ }^{3,21}$

\section{CONCLUSION}

In conclusion, the efficacy of ephedrine 30 $\mu \mathrm{g} / \mathrm{kg} \mathrm{BW}$ IV and lidocaine 2\% $40 \mathrm{mg}$ IV was comparable for reducing pain on injection of propofol in Indonesian adult surgical patients. Furthermore, ephedrine could be considered as an alternative premedication for reducing pain on propofol injection.

\section{ACKNOWLEDGEMENTS}

Authors would like to thank Director of Dr. Sardjito General Hospital, Banyumas District Hospital, Panembahan Senopati District Hospital, Orthopedi Special Hospital, and Saras Husada District Hospital for their permission to performed this study. Furthermore, we would also like to thank all subjects who participated in this study.

\section{REFERENCES}

1. Ready LB. Post operatif pain. In: Miller RD editor. Anesthesia $3^{\text {rd }}$ ed. New York: Churchill Living Stone Inc. 1990: 213-46.

2. Grauers A, Liljeroth E, Akeson J. Propofol infusion rate does not effect local pain on injection. Acta Anaesthesiol Scand. 2002; 46(4):361-3. 
3. Stoelting RK. Cyclooxygenase-2 inhibitors and nonspesific nonsteroidal antiinflammatory drugs. In: Stoelting RK, Hillier SC, editors. Pharmaco$\log y$ and physiology in anesthetic practice, $4^{\text {th }} \mathrm{ed}$. Philadelphia: Lippincot William \& Wilkins. 2006; 11:276-91.

4. Borgeat A, Wilder-Smith OH, Saiah M, Rifat K. Subhypnotic doses of propofol posses direct antiemetic properties. Anesth Analg. 1992; 74(4):539-41.

5. Tan $\mathrm{CH}$, Onsiong MK. Pain in injection of propofol. Anaesthesia. 1998; 53(5):468-76.

6. Nakane M, Iwama H. A potensial mechanism of propofol-induced pain on injection based on studies using nafamostat mesilate. Br J Anaesth. 1999; 83(3):397-404.

7. Picard P, Tramer MR. Prevention of pain on injection with propofol: a quantitative systemic review. Anesth Analg. 2000; 90(4):963-9.

8. Zahedi H, Maleki A, Rostami G. Ondansetron pretreatment reduces pain on injection of propofol. Acta Medica Iranica. 2012; 50(4): 239-43.

9. Ghafoor HB, Afshan G, Kamal R. General anesthesia with laryngeal mask airway: etomidate vs propofol for hemodynamic stability. O J Anes. 2012(2):161-5.

10. Fletcher GC, Gillespie JA, Davidson JA. The effect of temperature upon pain during injection of propofol. Anaesthesia. 1996; 51(5):498-9.

11. Ganta R and Fee JP. Pain on injection of propofol: comparison of lignocaine with metoclopramide. Br J Anaest. 1992; 69(3): 316-7.

12. Lyons B, Lohan D, Flynn C, McCarroll M. Modification of pain on injection of propofol. A comparison of pethidine and lignocaine. Anaesthesia. 1996; 51(4):394-5.

13. Fauzia B, Safia Z, Salim S, Sadqa A, Sultan ST. Intravenous ketamin attenuates injection pain and arterial pressure changes during the induction of anesthesia with propofol: a comparison with lidocaine. J Coll Physicians Surg Pak. 2007; 17:390-3.
14. Croston J, Espinosa V, de Henriquez L, de Jimenez L. Changes in the pain produced by the peripheral venous injection of propofol when it is combined with lidocaine or fentanyl. Rev Med Panama. 1992;17:199 -202.

15. Wall $R$ and Zacharias M. Effects of alfentanil on induction and recovery from propofol anaesthesia in day surgery. Anaesth Intensive Care. 1990;18:214-8.

16. Fujii $\mathrm{Y}$ and Itakura M. Comparison of lidocaine, metoclopramide, and flurbiprofen axetil for reducing pain on injection of propofol in Japanese adult surgical patients: a prospective, randomized, double-blind, parallel-group, placebo-controlled study. Clin Ther. 2008; 30(2):280-6.

17. Walker BJ, Neal JM, Mulroy MF, Humsi JA, Bittner RC, McDonald SB. Lidocaine pretreatment with tourniquet versus lidocainepropofol admixture for attenuating propofol injection pain: a randomized controlled trial. Reg Anesth Pain Med. 2011;36(1):41-5.

18. Kim HS, Cho KR, Lee JH, Kim YH, Lim SH, et al. Prevention of pain during injection of microemulsion propofol: application of lidocaine mixture and the optimal dose of lidocaine. Korean J Anesthesiol. 2010; 59(5): 310-3.

19. Lee HY, Kim SH, So KY. Prevention of microemulsion propofol injection pain: a comparison of a combination of lidocaine and ramosetron with lidocaine or ramosetron alone. Korean J Anesthesiol. 2011;61(1):30-4.

20. Eriksson AS, Sinclair R, Cassuto J, Thomsen P. Influence of lidocaine on leukocyte function in the surgical wound. Anesthesiology. 1992;77(1): 74-8.

21. Cheong MA, Kim KS, Choi WJ. Ephedrine reduce the pain from propofol injection. Anesth Analg. 2002; 95(5):1293-6.

22. James D and Timothy J. Admixture of ephedrine to offset side effects of propofol: a randomized controlled trial. J Clinical Anesth. 2009; 21:449. 